\title{
THE COLONIAL HERITAGE OF THE CENTRAL AFRICAN REPUBLIC: A LINGUISTIC PERSPECTIVE
}

\author{
By William J. Samarin
}

The lingua francas of Africa have not been used as they ought to be in the study of colonialism. The exceptions are rare: Fabian's recent book on Shaba Swahili, Baker and Corne's work on Isle de France Creole, and possibly Valkhoff's argument for the Portuguese Creole basis for Afrikaans. ${ }^{1}$ Although the literature on Afro-American speech is extensive, historical studies of its origins in Africa have barely begun. Alleyne's work, for example, throws very little light on the conditions in Africa that led to the emergence of African varieties of European languages. ${ }^{2}$

An opportunity to study colonialism from a linguistic point of view lies in explaining the origins of Kituba (the vehicular form of Kikongo), Lingala, and Sango. These three lingua francas, I believe, all emerged in central equatorial Africa in the last two decades of the nineteenth century. It was the same colonial enterprise undertaken by the French and King Leopold II of the Belgians that produced these languages. And the contexts in which they were developed were similar: a polylingual black work force, partly foreign and partly indigenous, had to have a means of communication for its own internal needs and for interaction with indigenous peoples. Since the black personnel engaged by the whites were at work, accomplishing the immediate and long-range purposes of the whites, these languages can very well be said to have originated as work languages. ${ }^{3}$

The history of central African colonization illuminates the history of the origins of these lingua francas, but the reverse is also true: sociolinguistic research on these languages introduces a point of view that was lacking in various histories of the area. These histories have been mostly political or

\footnotetext{
1Johannes Fabian, Language and Colonial Power: The Appropriation of Swahili in the Former Belgian Congo 1880-1938 (Cambridge, 1986); Philip Baker and Chris Corne, Isle de France Creole: Affinities and Origins (Ann Arbor, 1982); Marius F: Valkhoff, New Light on Afrikaans and "MalayoPortuguese" (Louvain, 1972).

${ }^{2}$ Mervyn C. Alleyne, Comparative Afro-American: An Historical-Comparative Study of Englishbased Afro-American Dialects of the New World (Ann Arbor, 1980).

${ }^{3}$ See William J. Samarin, "Language in the Colonization of Central Africa, 1880-1900," Canadian Journal of African Studies (forthcoming). This proposal goes against the traditional view that pidginization is mostly due to what European colonizers and traders did as they interacted with people in some way subordinate to them. A defense of the view goes far beyond the scope of this article, but some information is provided in several previous articles. See, for example, William J. Samarin, "Colonization and Pidginization on the Ubangi River," Journal of African Languages and Linguistics, 4 (1982), 1-42; "The Linguistic World of Field Colonialism," Language in Society, 13 (1984), 435-453; "Plurigenesis in Pidginization," Journal of Historical Linguistics and Philology, 2 (1985), 100-119; and "Communication by Ubangian Water and Word," Sprache und Geschichte in Afrika, 6 (1984/1985), 309-373.
} 


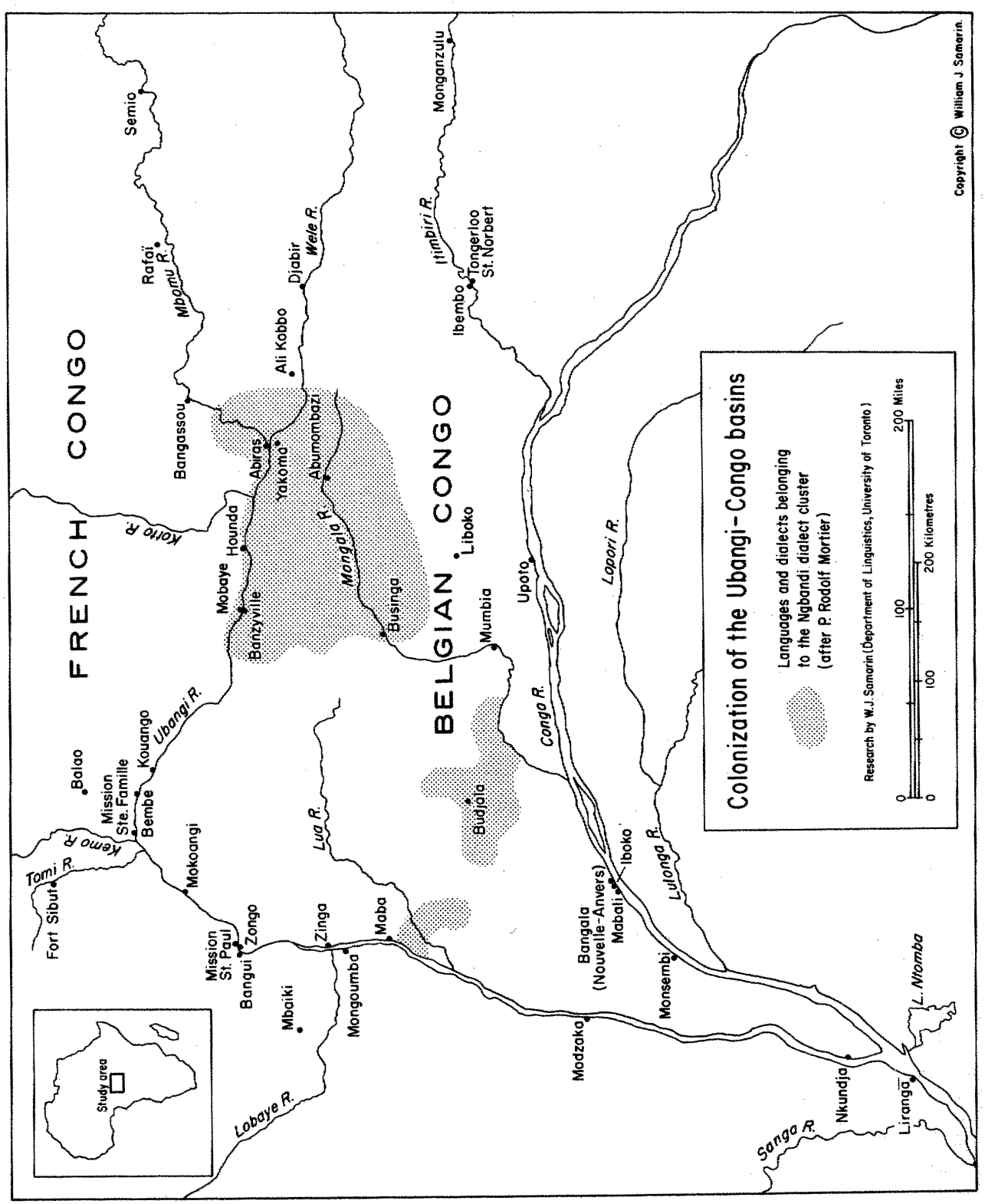


economic; very few have been ethnohistorical, ${ }^{4}$ and none has been a history of labor. Linguistic history changes the historiography of the French and Belgian territories in the nineteenth century. The asking of certain questions helps in the elucidation of events that took place and provides a critique of reports of whites who were involved in colonization: for example, who was talking with whom? what were the contexts of the communications? what relations existed between the interlocutors? and so on. These same kinds of questions bear also on the work of the linguistic historian, in the present case the one trying to unravel the history of Central Africa's lingua francas.

These are the kinds of questions that are posed in any ethnography of speaking when the task is a synchronic one. The ethnographic task in this case, of course, is to describe the differences in the purposes to which speech is put and the way it is organized for these purposes, for discourse is the consequence of the functions of language as it is that of the social roles of interlocutors. It is clear, therefore, that the explanation of the origin of Africa's lingua francas starts with this same perspective; it adds a temporal dimension, however. Situations changed, as did participants and purposes. The first contacts between the personnel of exploring parties and the indigenous people were probably at first by gesture, when bilingual guides were not available. And there must have been many, many situations when bilingual intermediaries were not around. ${ }^{5}$ When the black personnel of the colonizing forces began to acquire something of the indigenous languages, they could engage directly in trade; they could also get other things that the whites needed - such as firewood, porters, or canoers. From one point of view colonization changed very quickly in the first twenty years.

The number of foreign blacks arriving in an area - whether they were from East or West Africa, or from other parts of Central Africa now under white control - increased quickly and greatly. Culture contact was intense. These changes were reflected in the lingua francas that emerged. At the same time, the new languages made these changes possible. The history of Central Africa is therefore incomplete without language history.

\section{The Emergence of Sango on the Ubangi River}

The imprint of colonization, to take one example, is found in the Sango language, since independence the national language of the Central African Republic. Its very existence points to the situations that obtained in the Ubangi River basin in the 1880 s and 1890s. There was no lingua franca there when in 1888 Alphonse

\footnotetext{
${ }^{4}$ See, for example, Robert W. Harms, River of Wealth, River of Sorrow: The Central Zaire Basin in the Era of the Slave and Ivory Trade 1500-1891 (New Haven, 1981); Mumbanza mwa Bawele, "Histoire des peuples riverains de l'entre Zaire-Ubangi: évolution sociale et économique (ca. 1700-1930)" (Lubumbashi, Université Nationale du Zairre, Thèse doctorale, 1980), 2 vols.; Jan Vansina, The Tio Kingdom of the Middle Congo 1880-1892 (London, 1973).

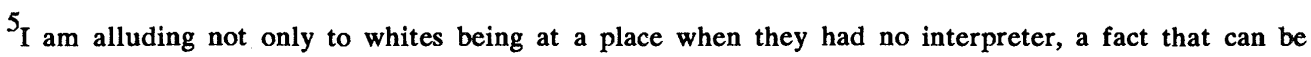
documented from archives, but also to those circumstances when, for example, a Senegalese soldier was a garde pavillon at some village, where his job frequently was to obtain food provisions for the white post and to recruit workers from among the villagers.
} 
Vangele first went up the river on behalf of King Leopold II east of what became Bangui. The attempt to demonstrate the contrary misreads some of the sources and is based on insufficient data. ${ }^{6}$ There had been, I claim, no need for a lingua franca, understood as a language that is used as a means of communication by people who otherwise have no language in common. ${ }^{7}$ The inhabitants of the banks of the Ubangi River were in contact with each other and with the nearby inhabitants of the hinterland before whites arrived. Although relations were not always pacific, there was trade among them. We can suppose that marriages were contracted between riverine people just as marriages were contracted between Sango and Yakoma people and, for example, Nzakara, who inhabited the northern hinterland of the Ubangi basin. Evidence for the latter marriages comes from the time of Vangele's first appearance at what came to be Banzyville, right in the midst of Sango people. ${ }^{8}$

Therefore what characterized the area was bilingualism on the part of individuals who, by marriage, trade contracts, or captivity, had acquired one or more of the region's languages. (Multilingualism is a predictable characteristic of human contact; the emergence of lingua francas, on the other hand, occurs as

\footnotetext{
${ }^{6}$ Marcel Diki-Kidiri, "L'Expansion du sango en Centrafrique," in Jean-Pierre Caprile, ed., L'Expansion des langues africaines: peul, sango, kikongo, ciluba, swahili, etc. (Paris, 1981); Samarin, "Plurigenesis."

${ }^{7}$ centrafricaine," Politique Africaine, 23 (1986), 83-99] appears to assume that the need was lack of communication between the Nzakara and Ngbugu, who were always in hostile relations with each other. This need was met, he claims, by the Dendi, whose speech is closely similar to riparian Sango, because they served as intermediaries between these two ethnic groups. This proposal is based on very little data, and arguments against it can be made on several grounds. A careful response cannot be undertaken here. It should be noted, in any case, that Dampierre made the claim years ago that it was the Yakoma who were intermediaries between these people, without, however, suggesting then nor since that this role led to their language becoming a lingua franca before whites arrived. See Eric de Dampierre, Un ancien royaume bandia du Haut-Oubangui (Paris, 1967), 181. Although Dampierre himself cited Girard for his statement [Henry Girard, "Yakomas et Bougous, anthropophages du Haut-Oubangui," L'Anthropologie, 12 (1901), 84], it was made earlier by Julien: "[Les Yakomas] servent d'intermédiaires commerciaux entre les Bougbous et les N'zákras, ennemis irréconciliables." Capitaine Julien, Du Haut Oubangui vers le Chari par le bassin de la rivière Kota (mai-octobre 1894) (Paris, 1898), 113.

${ }^{8}$ There were Nzakara villages just north of the Sango village of Mobaye, shown on Henri Bobichon's map of 1894, or 1891. "Mission du Haut Oubangui. Région des Ouaddas - Mobaye et Basse Kemo," Archives Nationales Section Outre-Mer, Paris (now Aix-en-Provence) [hereafter ANSOM], AF 707, No. 2. On the basis of interviews early in this century by Fr. Tanghe, we learn that when Alphonse Vangele arrived at the rapids of Banzyville in December 1887, Kbeme, brother of Kban-Kbitro, was returning to his village on the river from an Nzakara village, whose chief was Ligamba, situated three hours downriver and toward the interior. He had gone there to pay dowry for Sima, Ligamba's sister. Basile Tanghe, "L'Exploration de l'Ubangi 18841891," Revue Congo (1922). Also see Alphonse Vangele archives, Musée Royal de l'Afrique centrale, Tervuren, Belgium [hereafter MT], 17.5.1890, Cahier b.II, Ivoire I.
} 
special historical events. $)^{9}$ Moreover, it appears that riverine territories were controlled by the ethnic groups who lived on the banks and that passage up and down the river was not free to all who wanted it. There is no evidence for SangoYakoma colonies along the length of the Ubangi, as characterized the distribution of Bobangi traders on the Congo and Ubangi rivers at the time of the arrival of whites. ${ }^{10}$

In less than ten years there emerged on the Ubangi River a jargon or a pidgin, that Fr. Goblet in 1896 called "ce langage barbare de la rivière, qui fait que tu te comprends avec touts les tributs riveraines. Ce n'est pas une langue, mais un volapuck quelconque." 11 This is not the only attestation for the language from the 1890 s, but it is the earliest.

Sango came into existence, not because of traditional contacts between Sango-Yakoma people and other Ubangians, but because of Vangele's occupation of their territory in 1888 and 1889 , during which time he acquired over $8,000 \mathrm{kgs}$ of ivory from them. ${ }^{12}$ This and the period that lasted until the end of the century was labor-intensive. Vangele recruited - or forced into service - many SangoYakoma people. By the time of the Nile Expedition undertaken by the French in 1896-1897, when hundreds upon hundreds (one can say thousands) of these people

${ }^{9} \mathrm{I}$ offer this statement as a significant contribution to history from a linguistic (or more properly sociolinguistic) point of view. Unfortunately, at this time there is a dearth of information on the emergence of lingua francas as "special historical events." A work on this topic will attempt to answer the question, "Why did a lingua franca arise here, at that time, and not in other, even similar circumstances?" Such a work would deal with, among others, Aramaic, koiné Greek, Latin, Arabic, French, and in our day English. Lingua francas emerged as a consequence of trade, conquest, colonization, and colonial (or imperial) administration. And frequently they have been more or less altered as a result of language contact, the ones experiencing the greatest change being pidgins, some of which have become creoles. Research into the sociocultural contexts in which pidgins have emerged is still in its infancy. I have concerned myself with Central Africa, where we find Sango, Lingala, and Kituba (for which see Samarin, "The Origins of Bangala/Lingala," paper presented at the 20th Annual Conference on African Languages, University of Illinois at Champaign-Urbana, 1989), but also Chinook Jargon, a pidgin that arose in the fur trade on the Northwest Coast of North America at the end of the eighteenth and the beginning of the nineteenth centuries. Samarin, "Chinook Jargon and Pidgin Historiography," Canadian Journal of Anthropology, 5 (1986), 23-34; and "Jargonization before Chinook Jargon," Anthropological Research Notes, forthcoming.

${ }^{10}$ Harms, River of Wealth.

${ }^{11}$ Fr. Raoul Goblet, Journal du R[évérend] P[ère] Raoul Goblet, missionnaire apostolique de l'Oubanghy à la Mission de la Sainte Famille des Banziris. Chemise V, Bôte 181, Dossier B, Cahier 4, 31.7.1896, Archives privées de la Congrégation du Saint-Esprit, Chevilly-Larue, France [hereafter CSE]. The language must have started out as a jargon and then developed into a pidgin. A jargon is, as I understand it, an unsystematic form of speech that characterizes either a given speaker or a group of speakers, or both; a pidgin is a stabilized form of speech, the consequence of pidginization in a language contact situation. A pidgin can therefore be the object or goal of one's attempt at learning to communicate; a jargon by contrast does not provide such a grammatical model. The ambivalence in the above statement has to do with uncertainty about how long this process took, since we do not have linguistic information until 1908.

${ }^{12}$ Vangele papers, MT, 17.5.1890, Cahier b.II, Ivoire I. 
were used as canoemen and porters, ${ }^{13}$ the vernacular language of these people had been "corrompu" and was the "langue commerciale" of the Ubangi. ${ }^{14}$

The imprint on Sango was made by the black personnel of the expeditionary forces. Vangele's men on the voyage up the Ubangi River in 18871888 consisted of 12 so-called Zanzibari, 5 so-called Hausa, 2 Zulu, 2 "boys" (servants), and 21 "natives." On this trip Swahili was probably the dominant language among the personnel, because of the role of the Zanzibari personnel, but with the indigènes the emerging Bantu lingua franca may have been used called Bangala in the nineteenth century, subsequently known as Lingala. ${ }^{15}$ These natives were undoubtedly from the area of the confluence of the Ubangi and Congo, people who were to be called "Bangala."16 They are mentioned by this name in the expedition of 1889-1891, when there were 31 of them. The other black personnel consisted of 87 Zanzibari, 35 Hausa, 1 native "boy" and 2 unidentified women. ${ }^{17}$ There were only 11 whites on this voyage.

During the years that followed, foreign black personnel in the Force Publique of the Etat Indépendant du Congo diminished not only in real numbers but in proportion to the indigenous personnel that were introduced. Among these were thousands of so-called Bangala.

The French also relied on large numbers of foreign blacks, most of whom were so-called Sénégalais. Indeed, the militia that accompanied the French consisted entirely of men brought from the west coast. For example, among the 53 men accounted for in the Casimir Maistre expedition of 1891-1892 were, as I have analyzed the roster, speakers of the following language groups: 10 Fula, 2 Serer, 2 Themne, 8 Wolof, 4 Bambara, 1 Soussé, 1 Khasonke, 8 Sarakole, and 3 Susu-Dialonke. In addition, there were $11 \mathrm{Kru}, 2$ Gambians, and 2 Gabonese. ${ }^{18}$ That was at the beginning of the French occupation, Bangui having been founded only in 1889. A few years later the number of Sénégalais was $2800^{19}$

The French also brought in a large number of men they designated as Bakongo and Loango. (The latter are, of course, also speakers of a Kikongo language, probably Vili, but they were identified in this specific way.) These were used, to be sure, in transporting goods from the town of Loango to Brazzaville in very large numbers. ${ }^{20}$ Once in the service of the whites, they stayed on in

${ }^{13}$ Samarin, "Communication by Water and Word."

${ }^{14}$ Lettre de G[eorges] Bruel à sa proche famille, B2-17, 16.4.1897; B2-48, to his mother, 17.12.1897. Académie des Sciences d’Outre-Mer, Paris [hereafter ASOM], Correspondence privée.

${ }^{15}$ William J. Samarin, "Protestant Missions and the History of Lingala," Journal of Religion in Africa, 16 (1986), 138-163; "Origins of Bangala/Lingala."

${ }^{16}$ William J. Samarin, The Black Man's Burden: African Colonial Labor on the Congo and Ubangi Rivers, 1880-1890 (Boulder, Colo., 1989).

${ }^{17}$ Neither the ethnic origin nor the role of these women is specified. They probably were liberated slaves and served as auxiliary workers, possibly in the preparation of food.

${ }^{18}$ Comité de l'Afrique Française, 1892, Mission Maistre, Etat de renseignements du personnel noir emmené par la Mission, Brazzaville, 15 avril 1892; Casimir Maistre, A Travers l'Afrique centrale du Congo au Niger 1892-1893 (Paris, 1895).

${ }^{19}$ [Paul] Comte, Mission du Haut-Oubangui, 1894, ANSOM, AF 650, No. 2 (Cartothèque), GC XVI.13.

${ }^{20}$ Pierre Vennetier, Pointe-Noire et la façade maritime du Congo-Brazzaville (Paris, 1968). 
relatively small numbers for the exploration and occupation of the Ubangi basin. In January 1889, for example, there were 20 "travailleurs Loangos" at Modzaka on the lower Ubangi. ${ }^{21}$ Later that year, when Bangui was being established, there were 5 "ouvriers ou travailleurs de Loango" in addition to 9 Sénégalais and 8 "indigènes auxiliaires Balokis," who were probably from the area of what was then called Bangala (later Nouvelle Anvers, and now Mankanza). ${ }^{22}$ Two years later the chief French agent at Bangui had among all the workers 17 who were "libérables": 4 Loangos, 9 Bassa, and 4 Sénégalais. ${ }^{23}$ We will not document all the evidence there is for the presence of Kikongo-speaking workers on the Ubangi, noting only one more contingent of Bakongo. They were in the expedition of Victor Liotard, who left Brazzaville on 12 December 1891 with 32 Sénégalais, 2 servants (a Gabonais and a Bakongo), and 20 Balali (from the Lower Congo) and Bakongo porters. ${ }^{24}$

The final group of workers brought to the area were men from Liberia: $\mathrm{Kru}$, already mentioned, Vai, and Bassa. (Their significance in the development of Sango, revealed at least in one word, will be mentioned below). We know that there were Vai on the Ubangi River because Antoon Greshoff, field director of the Dutch trading company (Nieuwe Afrikaansche Handelsvennootschap), in 1891 lent Casimir Maistre a number of them. ${ }^{25}$ The source just cited does not mention the number. Elsewhere we learn that Greshoff, returning from the Sangha [River area], was providing 60 porters and 2 Europeans, taking them to Bangui. ${ }^{26}$ According to another report these "Vhyboys," numbering 50, were brought from Liranga (to which they presumably would have returned by river), to be used as porters. ${ }^{27}$

Bassa personnel came from a region, as far as I have been able to determine, next to that of the Kru. There were a number of them in the Paul Crampel expedition of $1891,{ }^{28}$ exactly 26 by one count. ${ }^{29}$ Another inventory lists

\footnotetext{
${ }^{21}$ Albert Veistroffer, Vingt ans dans la brousse africaine: Souvenirs d'un ancien membre de la mission Savorgnan de Brazza dans l'ouest africain (1883-1903) (Lille, 1931), 153.

${ }^{22}$ Charles de Chavannes, Lt. Gouverneur du Gabon et du Congo Français, Extrait de lettre, Libreville, 18.9.1889, ANSOM GC IV.D14a.

${ }^{23}$ E. Ponel, 4.1.1891, Archives Nationales, Aix-en-Provence, Archives du Gouvernement Général de l'Afrique Equatoriale Française [hereafter ANX], 2D5.

${ }^{24}$ Anne Claude de Mazières, La marche au Nil de Victor Liotard: Histoire de l'implantation française dans le Haut-Oubangui 1891-1899 (Aix-en-Provence, 1982), 24.

${ }^{25}$ Ponel, ANX 2D5, 4.2.1891.

${ }^{26}$ A. Dolisie, to Commissaire du Gouvernement, 14.8.1891, ANSOM GC IV.14.

${ }^{27}$ Casimir Maistre, "La Mission Maistre. Rapport." Bulletin du Comité de l'Afrique francaise dans l'Afrique centrale (1893[?]), pp. 2-11 (found as archives, ANX 2D10, 2); see also ASOM, Mission Maistre, Congo-Niger, 1892-1893, Carnets de route [8 carnets], No. 2: 24 avril - 12 juin 1892 (de Brazzaville à la Kémo), 1.

${ }^{28}$ Maistre, "A Travers l'Afrique centrale," 40.

${ }^{29}$ Dolisie, 30.7.1891, ANSOM GC III.13b.
} 
Kru, but no Bassa, among the 80 (or 87 ) porters of this expedition..$^{30}$ That same year Ponel had at least nine with him, possibly at Bangui. ${ }^{31}$ These may have been survivors of the Crampel expedition, that had been attacked by Senoussi's men, when Crampel was killed. In the following year Bassa are listed (but not numbered) among the workers at Bangui. ${ }^{32}$ Victor Liotard also had Liberians with him on the expedition to the sources of the Ubangi. ${ }^{33}$ Since Liberians, especially those who were called Kru, figured very highly in the work force of all whites of the 1880 s and 1890 s, we are justified in supposing that they were more prominent in the Ubangi basin than the available data reveal. ${ }^{34}$ The following section suggests linguistic evidence for this supposition.

As further evidence for the presence of West Africans in Central Africa, we note the fact that most of the soldiers at Boma in February-March 1893 were from the Guinea Coast. ${ }^{35}$

\section{Lexical Imprints in Sango}

It was understandable that Bantu languages should have left their imprint on Sango. They were spoken by the Zanzibari, by the so-called Bangala, and by the Bakongo who were brought as soldiers and workers by the French and Belgians. Today many Sango words are of Bantu origin. The exact or probable linguistic sources of these words have not yet been determined. I was therefore wrong in 1961 when I assumed that Lingala was the source of these words, simply because it was a coterritorial language - being spoken south of the Ubangi River in what was then the Belgian Congo. ${ }^{36}$ I knew little at that time about the colonial history of the region and did not realize that other Bantu languages were there (brought by workers) in the nineteenth century. The importance of Bantu words was nonetheless demonstrated. Of the 100 noncultural words used in glottochronological studies 6 were Bantu: "meat," "grease" (or "fat"), "hand," "many," "bird," and "walk." (In addition, "fly" was lexicalized as "walk in sky.") That Bantu words were already current on the Ubangi River in the 1890 s is clear from a mixed word list of d'Uzès, supposedly of the Gbanziri language, collected in $1892 .^{37}$ There we find six more words, in addition to "meat," that were cited in a

${ }^{30}$ Albert Nebout, "La Mission Crampel," Bulletin de la Société normande de géographie, 14 (1892), 221.

${ }^{31}$ Ponel, 4.2.1891, ANX 2D5.

${ }^{32}$ V. Largeau, Administrateur de l'Oubangui, to Administrateur principal at Brazzaville, Bangui 9.5.1892, ANX 4(3)D2.

${ }^{33}$ Victor Liotard papers, Journal (18.8.1891 au mai 1892, "Notes recopiées par la suite par un autre"), 22.9.1891.

${ }^{34}$ The role the Kru played in the colonization of Central Africa is discussed in Samarin, The Black Man's Burden.

${ }^{35}$ Frank Vincent, Actual Africa, or the Coming Continent: A Tour of Exploration (New York, 1895), 403-404.

${ }^{36}$ William J. Samarin, "The Vocabulary of Sango," Word, 17 (1961), 16-22.

${ }^{37}$ (Duchesse) d'Uzès, Le Voyage de mon fils au Congo (Paris, 1894). 
Bangala wordlist of $18999^{38}$ There are the following: "box," "mirror," "not," "do," "coward". (which later changed in meaning to "lazy"), and "tomorrow." These words themselves had different origins. For example, sanduku "box" comes from Arabic, probably via Swahili, and kokoriko "tomorrow" probably from the onomatopoeic representation of the sound of the cock in French. ${ }^{39}$ The point is that they seem to have been introduced in the Ubangi basin by those speaking one or more Bantu lingua francas. Some of these may have been introduced by Bangala, already a much-used language in the $1890 \mathrm{~s}$.

The intrusion of Bantu words in Ubangian wordlists is evidence not necessarily of the borrowing of these words into the indigenous languages so soon after the arrival of the whites, but of the usage on the part of Africans who served as sources of information for the French. It was they who were introducing Bantu words into the jargons they were creating. Thus, when Victor Liotard noted in his journal "quelques mots sangos" on 25 February 1892, he included the words for "de bonne heure" (the same as "tomorrow" above), "tissus," "miroir," and "viande" - all of Bantu origin. 40

The influence of Kikongo - that is, any one of its many dialects - has not yet been adequately identified in the Bantu loanwords of Sango. Since so many words, like likongo "spear," are common to Kikongo and other Bantu languages, one may not be able to identify their origin with certainty. This is not the case with Sango's verb yeke "be," which was an important innovation in the language: the Sango-Yakoma language does not have a copula, and it does not have a construction similar to the progressive form (such as yeke sara, "is doing") found in the pidgin. ${ }^{41}$ This is not the only Kikongo word in Sango, of course: bongo "cloth" is another one, recorded by Liotard in 1892.

In spite of the considerable number of Sénégalais who served in the French militia, none of their languages has left traces in Sango - at least, none have yet been identified (unless the word for "money," discussed below, is one of them). This is due in part to the fact that these soldier-workers were probably using the Bantu lingua francas by the time they arrived in the Ubangi basin. (The introduction of West African words for indigenous objects constitutes a special case which this paper is careful to attend to.) Unfortunately, there is no direct evidence for the assertion that Sénégalais were speakers of a Central African Bantu lingua franca. We assume it, because they were so long among the Bakongo, through whose territory goods were being transported from the coast to Brazzaville. 42

${ }^{38}$ Georges François Wtterwulghe, Vocabulaire d l'usage des fonctionnaires se rendant dans les territoires du district de l'Uele et de l'enclave Red jaf-Lado (Brussels, 1899).

${ }^{39}$ In this paper Sango words are not presented in their phonological form, for which see Bouquiaux et al., Dictionnaire sango-français (Paris, 1978).

${ }^{40}$ Liotard papers, ANSOM-Mi 213.

${ }^{41}$ William J. Samarin, "The Source of Sango's "be'," Journal of Pidgin and Creole Languages, 1 (1986), 205-223.

${ }^{42}$ William J. Samarin, "The State's Bakongo Burden Bearers," in Catherine Coquery-Vidrovitch and Paul E. Lovejoy, eds., The Workers of African Trade (Beverly Hills, Calif., 1985), 269-292. 
This is not the place to give a full account of the role the so-called Sénégalais played in the work force of the French; we can only cite a few facts. Savorgnan de Brazza, for example, had on his third voyage (that left France on 21 March 1883) 25 "tirailleurs algériens," 150 "laptots sénégalais," and 150 "noirs de la côte de Krou (côte de Guinée)." ${ }^{43}$ For the construction of Libreville in 1886 there were recruited 50 "laptots" from Sénégal in addition to $150 \mathrm{Kru}$ and other workers recruited at Biribi, Cavaly, and Accra. ${ }^{44}$ And in $1894 \mathrm{Mgr}$. Augouard wrote, "Nous faison venir à grands frais des ouvriers Noirs du Sénégal, de SierraLeone, du Gabon ...."45

\section{A West African Heritage}

The only West African word in Sango appears to be nginza "money." It is not only evidence of the presence of West Africans in the Ubangi basin, but it also demonstrates how much imprint a few foreigners can leave on a language. It is, moreover, a stimulus for further research on the West Africans who participated in the colonization of France's Haut-Oubangui in the 1890 s - if not in King Leopold's Etat Indépendant (discussed below).

The earliest attestations may be those of D'Uzès and Liotard, both for the year 1892, in the forms gouinza and kinja. There is an earlier record in Alphonse Vangele's journal somewhere around Cetema, not far upriver of Mobaye, but he does not use either of these words: "Nous achetons des pelles - il paraîtrait que c'est un peuple en amont appelé Bira qui les fabriquerait." ${ }^{46}$ Others use the word "pelle," 47 but "machette" is also used for what is identified as ginja. ${ }^{48}$ D'Uzès calls it merely a "plaque de fer," described by another as being, in his own record, 0.30 c. long and $0.15 \mathrm{c}$. wide, ${ }^{49}$ probably meaning 30 by 15 centimeters in size.

This particular iron object was generally recognized by whites as being a local currency, while apparently attributing to it also a practical function. D'Uzès glossed the word as "monnaie." Several writers recognize that it was "minted" (my term) by the Yakoma. It served for units of value above beads ("une petite cuiller" for one guindja in 1893) and below that of ivory or slaves. ${ }^{50}$ According to D'Uzès the Sango preferred using this currency to bayaka beads: one kinja would

\footnotetext{
${ }^{43}$ Marcel Guillemot, ed., Notice sur le Congo français: Exposition universelle de 1900; Colonies et pays de protectorat (Paris, 1900), 22.

${ }^{44}$ Dr. Ballay, Lt. Gouverneur du Gabon au Ministre de la Marine et des Colonies, Libreville, 1.10.1886, ANSOM GC XIV.1.

${ }^{45}$ Monseigneur Prosper Augouard, Correspondences, Brazzaville, 2.1.1894, Archives privées de la Congrégation du Saint-Esprit, Chevilly-Larue, France [hereafter CSE].

${ }^{46}$ Vangele papers, MT.

47 Georges Le Marinel, "La Région du Haut Ubangi," Bulletin de la Société royale belge de géographie, 1 (1893), 24.

${ }^{48}$ Cpt. Heymans, "La Zone Mokoangai," La Belgique coloniale, 29 (1896), 344.

${ }^{49}$ [Illegible name], "Rapport sur les diverses peuplades du Haut-Oubangui, Zone Amont-Rapides, tribus riveraines. Les Banziris," ANX 4(3)D3.

${ }^{50}$ Ibid.
} 
buy a chicken, 5-6 a goat, and 100 a "bel esclave."51 Others give its value as $30-40$ buying a slave and 50 for a wife ${ }^{52}$ or 100,200 , or even 500 for a wife. ${ }^{53}$ In 1899 at Bangui five were enough to "pai[er] les cadavres,"54 a figure, however, that seems in the light of Central African ethnography too low for avenging a murder - if indeed this is what the compensation was for..$^{55}$

One would not expect a foreign name for so important an indigenous object as money. ${ }^{56}$ Failing to find it in the thorough dictionary of Fr. Lekens ${ }^{57}$ and various dictionaries of Bantu languages, I would not have thought of considering a West African source had it not been for an accidental discovery in 1983 of a similar form in Amharic: ganzab (the vowel being similar to that of English cut) "money." Since speakers of that language had nothing to do with the Ubangi basin, I immediately considered Arabic. It has kenz for "wealth," but no dictionary of Chadian Arabic - a language that we can assume emerged in the slaving activity of Muslims north of Yakoma territory ${ }^{58}$ - reveals a cognate, and persons knowledgeable in this language could not provide something analogous to kinja. But sensing now that Arabic was at the bottom somewhere, I began to look to West African languages, where I supposed Arabic may have had its

${ }^{51}$ D'Uzès, Le Voyage de mon fils, 220.

52 "Rapport sur les diverses peuplades," ANX 4(3)D3.

${ }^{53}$ Georges Bruel to his mother, 17.12.1897, ASOM B2-48.

${ }^{54}$ M.-C. Dias-Briand, "Les Archives de Joseph Briand médecin à Bangui 1898-1900" (Aix-en-Provence, Université de Provence, Mémoire de maitrise, 1982), 108.

${ }^{55}$ The Yakoma mined iron ore, refined it, and produced all kinds of objects in it. Smithing was not unknown among other peoples of the area, even some of the hinterland peoples, but it is clear from all reports that the Yakoma surpassed all others in the quantity and quality of the material that was produced. Research on their industry is still being pursued, but what we know about it compells admiration. The Mbomu-Uele area seems to have been the location of the mines. One map has the following notation on the left bank of the Uele, opposite a place called Pata: "Montagne de minerai de fer. [E]xcessivement riche. Provenance de tous les fers travaillés dans le M'Bomou, l'Ouellé, l'Oubangui, chez les Bougbous et les N'Sakaras." Elsewhere on this map are noted these comments: "Industrie: grand nombre de forgerons, fabriquants des kindjas (monnaie)[,] des armes, des outils, des cloches. - Pikissa est le plus grand centre de cette production;" "Commerce: Grand commerce de minerai de fer avec les Yakomas du M'Bomou, de l'Oubangui et avec habitants de l'intérieur en échange de chèvres et de perles" [Paul Comte, "Note sur la situation des effectifs dans le Haut-Oubangui," Juillet 1895, ANSOM GC XVI.13]. Elsewhere we learn that Abiras, at the mouth of the Mbomu, was also inhabited by iron workers [Albert E. Baratier, Vers le Nil: Souvenirs de la Mission Marchand de Brazzaville a Fort Desai. Ouvrage inédit (Paris, 1897), 25-26], but this is still in Yakoma territory.

${ }^{56}$ Baratier [Vers le Nil, 17] identified it as a Gbanziri word, probably because it was being used by these people, many of whom had served the French, and probably also the Belgians, as canoemen [Samarin, "Communication by Ubangian Water and Word"]. As we have seen, by this time there was already a Ubangian lingua franca on the river. It is reasonable to suppose that the word was used in that language. However, the simplest explanation would be borrowing directly from the Liberians employed by the Dutch trading firm at, for example, Ouaddas, where there was a "factory" at least by 1892. Largeau to Liotard, Bangui, 2.7.1892, ANSOM-Mi, 213-Mi 1, Dossier 1.1.

${ }^{57}$ Benjamin Lekens (O.F.M. Cap.), Dictionnaire ngbandi (Ubangi, Congo Belge): Français-ngbandi, ngbandi-français (Anvers, 1952).

${ }^{58}$ Dennis D. Cordell, Dar al-Kuti and the Last Years of the Trans-Saharan Slave Trade (Madison, 1986). 
influence. ${ }^{59}$ Nothing at all in the dictionaries for Bambara and Wolof, the two most obvious languages that the Sénégalais would have used, has been found to resemble kinja.

The source has now been traced to the Mende-speaking area where Sierra Leone, Guinée, and Liberia meet. Among the Toma, for example, as described by Fr. Raoul Bunot, the money consists of a small iron bar about thirty centimeters long and about the size of a pencil in diameter. ${ }^{60}$ But although Fr. Bunot calls the money guinze, he says that the Toma call it koli. He was obviously naming money in some general way in another language: i.e., what was commonly called ginze in the area, the Toma in their own language called koli. ${ }^{61}$ Porteres, writing more thoroughly on the subject, also uses the word as a loanword: he calls the iron money ginze, but he notes that in different languages there are different names. Only in Kisi, Malinke, and Konian, according to him, does it go by this name. What appear to be phonological variants occur in other languages: gbenze and gweze. ${ }^{62}$

We have obviously traced the geographical area from which Sango's nginza comes. I suggest that when West Africans arrived in the Ubangi basin and encountered iron money being used just as it had been "at home," they gave it the name they had used in West Africa. Portères notes, for example, that iron money had been described for Sierra Leone and for Liberia - in the latter place among the Vassa, which I take to be Basa. It poses no problem to account for the addition of the "n" (i.e. from kinja to nkinja to nginza): this was undoubtedly a hypercorrection on the part of some speakers who believed that because so many words they were familiar with were said by some people with initial "n" and by

\footnotetext{
${ }^{59}$ The Arabic root, possible originally a Persian loan, is found elsewhere in Africa. Some forms of Swahili have kengele for "cloche, clochette" [Ch. Sacleux, Dictionnaire Swahili-Français (Paris, 1939)], and kengee in kengee ya mkuki "fer de lance" [Sacleux, Dictionnaire, 2nd ed. (Paris, 1949)]. Swahili may also be the source, through the Zanzibari members of the Force Publique in the nineteenth century, of likenzi (plural makenzi) for iron ore from "roches latériques" in what may be the Libinza language of Zaire (Mumbanza mwa Bawele, "Histoire des peuples riverains," I, 236). Also in Zaire, "dans la région de la Lukenié," one finds kundja, "une sorte de fer de lance ébauché" once used as currency [Alfred Mahieu, Numismatique du Congo, 1485-1924, 2nd ed. (Brussels, 1924), 22-23.] If this is indeed a cognate of kinja, I would prefer to consider its having been introduced by the same people who introduced the word to the Ubangi basin, for West Africans also worked in the Congo Free State in considerable numbers.

${ }^{60}$ Raoul Bunot (S. Sp.), "Une Monnaie guinéenne: Le Guinzé," Annales des Pères du Saint-Esprit 55 (1939), 163-165. I am grateful to Dr. Peter Westerdijk, who has a rich knowledge of Yakoma metallurgy and an important collection of their handiwork, for this reference. See Peter Westerdijk, The African Throwing Knife: A Style Analysis (Utrecht, 1988).

${ }^{61}$ However, Fr. André Prost (personal communication) informs me that ginze is a Loma word (to use the common spelling for this ethnic group) and that koli is the generic word for "iron." The use of ginze in dowry is mentioned in Jacques Germain, Peuples de la forêt de Guinée (Paris, 1984), 167. In this work one gets the impression that the word was used among the Kpelle as well. As for koli, I find an almost identical word (kolu) being used in 1868 at a place a Liberian traveller called Mahommadou, possible today's Mogamadou in Guinée. A girl of nine years of age was being sold in the market for 9,000 of them, equivalent at that time to about fifteen Liberian dollars. If I read the account correctly, the kolu had a long triangular shape. Benjamin J. K. Anderson, Narrative of a Journey to Musardu, the Capital of the Western Mandingoes ... [1870] (new edition, London, 1971), 109, 110.

${ }^{62}$ Roland Portères, "La Monnaie de fer dans l'Ouest-Africain au vingtième siècle," Journal d'Agriculture tropicale et de botanique appliquée, 7 (1969), 97-109.
} 
other people without, this was one that should have one at the beginning. Its earliest attestation is 1897 , in a letter by a missionary at S. Paul des Rapides near Bangui. ${ }^{63}$ And "nj" (or "ndj") and "nz" are, putting it simply, interchangeable in languages and dialects of the Ubangi basin.

In view of the generality of the term ginze, I am not yet in the position of saying with certainty what ethnic group was responsible for identifying Yakoma iron money with the West African one. More than one group of West Africans may have introduced their word - or the lingua franca word - for the iron money. It was noted above that two forms were recorded in 1892: gouinza and kinja. In other words, there was a form with labialization of the velar consonant ("gw") and one without. This variation occurs in West Africa itself. Since it is not very likely that a single ethnolinguistic group would use more than one of the variants, we have to assume that members of different speech communities were represented among the black workers who used the iron money. That the nonlabialized form won out is a significant fact. It may suggest the numerical preponderance of its users, or simply their importance at a critical time in the emergence of Sango, whatever their number was.

It seems highly unlikely that the Kisi, Kpelle, or Loma were direct carriers of the word to Central Africa. They are never mentioned among those who were recruited for the Central African work force. Recruiting was going on in the 1880s and 1890s along the coast, and it is doubtful that hinterland peoples were available for recruiting where boats could anchor. It seems most prudent at the present time to assume that the word was introduced in the Ubangi basin by either the coastal people (such as the Kru, Vai, and Basa) or some of those broadly called Sénégalais (or both) - whoever had or might have had contact with interior peoples using iron money. At the present time, a Liberian provenance seems most likely.

With respect to the Sénégalais, nonetheless, it may be significant that there was a French military post at Diakolidougou, in what seems to have been the territory of iron money, during the years $1888-1894{ }^{64}$

I am inclined to believe that it was the Liberians employed in the Ubangi basin who introduced the word. They might have learned it from so-called "Mandingo" traders from what is now Guinee, who came to the coast. That the "Mandingo" did so is documented by a Liberian explorer who in 1868 went to what he called their capital, Musardu (or Musahdu), which is probably to be identified with today's Moussadougou, a distance, he says, of about twenty-five to thirty days' march from Monrovia. He said that "Their avidity for trade has drawn them from their treeless plains to the Atlantic oceans." ${ }^{65}$ That the Vai at least were in contact with the "Mandingo" is clear from this account. The traveller found at Boporu, for example, that among the many different "tribes"

\footnotetext{
${ }^{63}$ Félix Sallaz to Monseigneur [Augouard], St. Paul [des Rapides], 8.10.1897, CSE.

${ }^{64}$ Jacques Germain, Peuples de la forêt (Paris, 1984), "Carte historique," opposite p. 116. It has been well established that the men who were recruited from the Sudan as tirailleurs and came to be known as Sénégalais in Central Africa were from many different ethnic groups, and that many of them were of slave origin. It is among people like these where we might look for the use of kinja. One is of course obliged to demonstrate that the men came or could have come from the kin ja area.

${ }^{65}$ Anderson, Narrative of a Journey, 6, cf. 7 and "Note on map."
} 
located there were Mandingo and Vey. Indeed, the language of the latter was "used for general communication" (in other words, it was a lingua franca). ${ }^{66}$

When it is suggested that Liberians may have been responsible for introducing the word, it is not to be deduced necessarily that the men were all recruited from Liberian soil. Kru, for example, travelled a considerable distance along the coast and settled in Sierra Leone and what is today the Ivory Coast. ${ }^{67}$ It is not unreasonable to suppose that some were recruited in areas far from home, at places, in fact, where they thought they could most easily find employment with Europeans. If Ivory Coast was one of these places, then it is worth noting that words similar to those already cited, namely, gwinzin or guinze, were taken there by the Kooroko. The Kooroko traded in this iron currency both in Ivory Coast and Guinée. ${ }^{68}$

A Liberian source for Sango's nginza is here considered to be the most reasonable in light of the facts now at our disposal. First, we should note that the earliest attestations (1892), as we saw above, coincided with the use of Liberians by French explorers. For just this period it has been demonstrated that explorers frequently cited as indigenous words those that actually were brought by their workers from outside the immediate area. ${ }^{69}$ Second, Liberians must have constituted a large part of the work force of the Dutch trading company. Its director, as we have seen, was [not?] able to do without a considerable number of them, possibly in the desire to ingratiate himself with the French who were getting established on the right bank of the Ubangi river. The firm must certainly have come soon after the penetration of the basin by Alphonse Vangele in 1887, for its activities seem to have been pursued hard on the heels of King Leopold's agents. For example, a trading post ("factory") was established at Kinshasa in May 1886, and in October 1887 its first steamer was launched at Stanley Pool, the Holland. ${ }^{70}$ Although we have no information about when the Dutch firm established its first trading posts on the Ubangi, we know that in 1892, the critical date already cited, there was one at Yakoma. ${ }^{71}$ Another was located at Abiras. ${ }^{72}$ What is important about these locations is that they were among the very people who were "minting" the iron money. In fact, Abiras is the same name as Bira, cited above as that of an ethnic group ("a" being the local language's plural prefix and "s" being the French suffix). (We have already noted the presence in 1892 of Dutch trading at Ouaddas, whose people, the Gbanziri, were then using the foreign word.)

\footnotetext{
${ }^{66}$ Ibid., 39.

${ }^{67}$ Christine Behrens, Les Kroumen de la Côte occidentale d'Afrique (Bordeaux, 1974).

${ }^{68}$ Jean-Loup Amselle, Les Négociants de la savanne: Histoire et organisation sociale des Kooroko (Mali) (Paris, 1977), 137.

${ }^{69}$ Samarin, "Colonization and Pidginization."

${ }^{70}$ Hamid ibn Muhammad, L'Autobiographie de Hamed ben Mohammed el-Murjebi, Tippo Tip (c. 1840-1905), edited by Fr. François Bontinck (Brussels, 1974), 276, note 453.

${ }^{71}$ V. Liotard, Bangui, 12.1.1891, ANX 2D7.

${ }^{72}$ Capitaine Julien, "Valée de la Rivière Kota explorée par le Capitaine Julien, 1er mai-5 octobre 1894," ANSOM AF 708.
} 
In light of these facts a Senegalese source seems less likely. That is, given the presence of Liberians and the lack of information about the origins of the Senegalese troops, we are led to argue for a Liberian borrowing. Even less likely is the role of the Belgian work force. West Africans did not figure significantly among the Congo Free State's black personnel.

\section{Conclusion}

In addition to documenting the varied linguistic sources for the vocabulary of Sango, the national language of the Central African Republic, this paper throws light on the way a multilingual work force goes about creating a jargon with which to communicate with local peoples. The paper suggests that either a few people had more linguistic influence than might be imagined from their numbers or that there were many more people than records have revealed to this date. Finally, the paper also stimulates the investigation of the work force that colonizers had with them in the occupation of Central Africa in the last two decades of the nineteenth century. It will do us well, for example, to look more thoroughly into archives and published material for information about West Africans. But perhaps it is still not too late for inquiries to be made among the descendants of those early African explorers.

The study of loan words suggests people's attitudes to their experience and to the language they speak. It is to be noted here that West Africans did not adopt the name of iron money in the language they were creating into a pidgin; they used their own word. We can assume that the kinja was perhaps first and more frequently used among the West Africans themselves as they talked about how much this or that cost and then they introduced this word into the jargon they used in communicating with Ubangians.

From this study we also learn that the foreign personnel had a great deal of commercial dealings with the local people, and that these dealings were more than trivial: they were paying for things that could only - or more efficiently be bought with iron money. We saw above that one kinja would buy a chicken, of which many would have been bought for the workmen's meals. If they did not actually deal in kinja - and it is not likely that they could travel around with large numbers of them - they were quoted prices in this currency, which had to be converted into other kinds. (A small spoonful of beads, as we saw above, was equivalent to one kinja.) This was a common practice throughout Central Africa. ${ }^{73}$

\footnotetext{
${ }^{73}$ The writing of this history started with my discovery of ganzab in Amharic, and was followed up with a conversation with Eric de Dampierre, a specialist on the Yakoma and Nzakara, in 1984. His views were written up in a brief report (Note Musée des Sciences de l'Homme, no. 17, 1984). The present paper was independently researched. The research, undertaken at different times over nearly two decades, was funded by the following organizations: the International Studies Programme of the University of Toronto, the Social Sciences and Humanities Research Council of Canada, the American Philosophical Society (USA), the Social Science Research Council (USA), and the Centre National de la Recherche Scientifique (France). Their help is gratefully acknowledged.
} 